\title{
Evaluation of stress resistance of grape remote hybrids, carrying Vitis rotundifolia Michx. introgressions
}

\author{
Volynkin V.A., Likhovskoi V.V., Vasylyk I.A.*, Lushchay E.A., Gorislavets S.M., \\ Volodin V.A., Risovannaya V.I., Potokina E.K. \\ All-Russian National Research Institute of Viticulture and Winemaking "Magarach” RAS, Yalta, Russia \\ *email: kalimera@inbox.ru
}

In the Vitaceae family, species are distinguished that are resistant to individual or complex pathogens and frost. One such species is Vitis rotundifolia. In the process of research, new scientific knowledge has been obtained about the inheritance of traits of grape resistance to pathogens that cause mildew and oidium diseases and frost from Vitis rotundifolia. The objects of research were the recombinant lines of three populations from the crossing of the maternal form $q$ M. No. 31-77-10 with hybrids of the progeny of Vitis rotundifolia. The frost resistance trait is not due to specific genes, which is typical for other traits, but is determined by the genotype of the plant as a whole. It was found that in breeding for frost resistance, the use of the form $q \mathrm{M}$. No. 31-77-10 has the character of a specific combinational ability to inherit resistance. As a result of laboratory screening in the population +M. No. 31-77-10 x [DRX-M5-734 + DRX-M5753 + DRX-M5-790], more than $40 \%$ of recombinants are characterized by a high degree of resistance to frost $\left(-24{ }^{\circ} \mathrm{C}\right)$, transgressive recombinants $(6 \%)$ with a very high degree of resistance $\left(-27^{\circ} \mathrm{C}\right)$. The maternal genotype $\rightarrow \mathrm{M}$. No. 31-77-10 does not have alleles of resistance of the Runl locus and is more strongly affected by powdery mildew in the field than in the paternal genotypes. The percentage of powdery mildew spread on vegetative organs in recombinant populations on average over the years of research varies within 3.2-17.1, 0.3-17.7 and 0.6-5.2\% respectively. As a result, almost all recombinant hybrids, having received a resistant allele from the paternal genome, are highly resistant to powdery mildew.

Acknowledgements: The work was supported by the Russian Science Foundation (Project No. 20-16-00060). 